\title{
The effect of low calcium intake and vitamin $D$ supplements on bone structure in young growing dogs
}

\author{
BY J. R. CAMPBELL \\ Department of Veterinary Surgery, University of Glasgow \\ AND T. A. DOUGLAS \\ Department of Biochemistry, University of Glasgow
}

(Received 12 October 1964-Accepted 7 April 1965)

Osteoporosis is a relatively common disorder encountered in young dogs (Campbell, I960). Its aetiology has been the subject of a controversy over the last few decades, which has arisen from the fact that a similar disorder sometimes occurs in the human infant; this disorder has been shown to be genetically based and has been specifically called osteogenesis imperfecta (Herndon, 1956). It has been claimed by Schnelle (1940) that there is a genetic basis for osteoporosis in the young dog, although final proof has never been produced. Defects in the nutrition of the young growing dog have also been suspected as playing a part in the aetiology of the disease (Riser, I96I).

Nutritional factors liable to be of importance in bone formation are the intakes of calcium and phosphorus. The absorption, utilization and excretion of $\mathrm{Ca}$ are affected by the amount of vitamin $\mathrm{D}$ available to the animal. A low Ca intake has been shown to cause bone fragility in kittens (Greaves, Scott \& Scott, $195^{8}$ ). Vitamin D is known to improve the absorption of $\mathrm{Ca}$ from the gut (Harris \& Innes, 193I), but resorption of bone has also been described when vitamin $\mathrm{D}$ intake has been high, particularly when the diet has been low in Ca (Carlsson \& Lindquist, 1955).

An example of the type of daily diet that has been given in a clinical case of bone fragility in a pup is I lb minced meat, $\frac{1}{2}$ pint milk, $\frac{1}{4} \mathrm{lb}$ wholemeal bread and glucose, I teaspoonful cod-liver oil, one haliborange tablet (Allen \& Hanbury Ltd) and $\frac{1}{2}$ teaspoonful of bone meal. The approximate contents of $\mathrm{Ca}, \mathrm{P}$ and vitamin $\mathrm{D}$ in this diet according to McCance \& Widdowson (I960) are $0.15 \mathrm{~g} \mathrm{Ca} / \mathrm{1} 00 \mathrm{~g}, 0.275 \mathrm{~g} \mathrm{P} / \mathrm{1} 00 \mathrm{~g}$ and 1000 i.u. vitamin $\mathrm{D}$ on a wet weight basis.

The investigation now reported has been undertaken in order to obtain further evidence on the nutritional aspects of osteoporosis in the young growing dog.

\section{EXPERIMENTAL}

Animals. Sixteen mongrel pups of both sexes from five unrelated litters were used. They were between 6 and ro weeks old and their nutritional history before the investigation was largely unknown. Radiography was carried out to eliminate animals with gross bone abnormalities and two complete litters were rejected on these grounds.

Diets. The diet consisted mainly of meat and unfortified bread (to which no calcium 
had been added) and was made up of $60 \%$ tinned meat, $30 \%$ dried bread and $10 \%$ sugar. 'This diet was found on analysis to contain $0.08-0.10 \% \mathrm{Ca}$. The diet and drinking water were allowed $a d$ lib. According to the figures given by McCance \& Widdowson (1960), this diet would contain only a trace of vitamin D. Vitamin D was given in the form of cod-liver oil or halibut-liver oil, and the dosage was so arranged that equal volumes of oil were given. This meant that the animals receiving the halibut-liver oil were receiving ten times as much vitamin $\mathrm{D}$ as those having the cod-liver oil.

The animals were divided into three groups.

(A) Five pups received the experimental diet supplemented with $\mathrm{Ca}$ and $\mathrm{P}$ in the form of bone meal so that the mineral contents were $0.5 \% \mathrm{Ca}$ and $0.3 \% \mathrm{P}$ approximately. These were the control animals on high $\mathrm{Ca}$ intake and received no vitamin $\mathrm{D}$ supplement.

(B) Four pups received only the experimental diet containing $0.08-0.10 \% \mathrm{Ca}$ and $0.13-0.15 \% \mathrm{P}$.

(C) Five pups received this diet with no added minerals but with roo i.u. vitamin $\mathrm{D} /$ $\mathrm{kg}$ body-weight given daily by mouth, each pup being dosed separately. Two further pups received similarly rooo i.u. vitamin $D$ daily.

Procedure. The animals were given a regular clinical examination and were weighed every 2 weeks. Each week blood samples were taken, Io $\mathrm{ml}$ being collected from the jugular or cephalic vein. Except when whole blood samples were required, the blood was transferred without delay to a heparinized tube, mixed and centrifuged immediately. Radiological examination of the forelimbs was carried out routinely every 2 weeks and the hind limbs and pelvis were included when there was clinical evidence of abnormality in this region. As a rule, animals were maintained on the diets for about 3 months, after which time they were killed by an overdose of barbiturate (Euthatal; May \& Baker Ltd).

Balance studies. Two pups from each group were confined throughout the experiment in metabolic cages which were situated in a room with a north exposure in which the temperature was thermostatically controlled at $68^{\circ} \mathrm{F}$. The animals were maintained for 8 weeks on the diet and then $\mathrm{Ca}, \mathrm{P}$ and nitrogen balances were carried out on these pups, the balance periods lasting over 3 days. During each balance period the food supplied to each animal and the food rejected were accurately weighed. No check was kept on water consumption, the water supply for the Glasgow area containing only minute amounts of minerals.

Urine was collected into a large $\left(2 \frac{1}{2} 1.\right)$ jar under each cage. Conc. $\mathrm{HCl}(5 \mathrm{ml})$ was put into each jar to act as a preservative. Faeces were collected daily. At the end of the balance period the cages were washed down with distilled water, and the washings were added to the urine collection.

Analytical methods. Samples of food were weighed, homogenized with water and portions taken for determination of $\mathrm{Ca}, \mathrm{P}$ and $\mathrm{N}$. Faeces were dried in an oven at $\mathrm{II}^{\circ}$ and weighed, pulverized, and samples taken. The total volume of urine was measured and samples were taken. $\mathrm{N}$ was determined by the micro-Kjeldahl method described by Kabat \& Mayer (I96I).

Samples of food and faeces were ashed in a muffle furnace at $500^{\circ}$ and the residue was 
dissolved in $5 \mathrm{~N}-\mathrm{HCl}$. $\mathrm{P}$ in plasma, urine, faeces and food was measured by the method of Fiske \& Subbarow (I925). If the urine contained more than $13 \mathrm{mg} \mathrm{P} / 100 \mathrm{ml}$, the $\mathrm{P}$ was removed by passing the urine through an amberlite $\mathrm{IR}-4 \mathrm{~B}$ resin (British Drug Houses Ltd) column in the chloride form. Concentrations of $\mathrm{P}$ below $13 \mathrm{mg} / 100 \mathrm{ml}$ do not interfere with the determination of $\mathrm{Ca}$ (B. E. C. Nordin, I96r, personal communication).

$\mathrm{Ca}$ in plasma, urine, faeces and food was measured by the method of Kramer \& Tisdall (1921), or by the EDTA titration method (Williams \& Moser, 1953), using murexide and a photoelectric titrator. Plasma alkaline phosphatase was determined by the method of King \& Armstrong (1934) as modified by King, Haslewood \& Delory (1937). Blood urea levels were determined as described by Varley (1958).

Copper in whole blood and liver was determined by a modification of the method of Eden \& Green (r940). The liver samples were obtained at the end of the experimental period.

Haematology. Haemoglobin was determined by the oxyhaemoglobin method (Varley, 1958), and erythrocyte counts were made with a haemocytometer.

Histological preparation. Sections of bone were fixed in $10 \%$ formalin $(4 \%$ formaldehyde $w / v)$, decalcified with $10 \%(v / v)$ formic acid and embedded in paraffin wax. Sections were stained with haematoxylin and eosin.

\section{RESULTS}

Clinical and radiographic examination. All the pups in groups A and B showed satisfactory gain in weight, increasing at a mean rate of $340 \mathrm{~g}$ and $400 \mathrm{~g}$ per week, respectively. This represents a mean weekly increase of $9 \%$ of the initial weight. The animals in group $\mathrm{C}$, which were receiving the lower dose of vitamin $\mathrm{D}$, showed an average weekly increase of $300 \mathrm{~g}$ ( $7 \%$ of initial weight). With the daily dose of vitamin D of $1000 \mathrm{i} . \mathrm{u} . / \mathrm{kg}$, however, the mean weekly increase was reduced to $100 \mathrm{~g}$ ( $2 \%$ of the initial weight). These differences were also reflected in the food consumption.

Skeletal changes were absent in the control animals, whereas in groups B and C changes became evident. The pups in group $\mathrm{B}$ (low $\mathrm{Ca}$ intake) showed typical rachitic changes with bending of the legs, plantigrade stance and enlargement of the epiphysial line (Pl. $1 a$ ). Slight lameness was seen in some but did not persist. Cortical lamellation and loss of bone density were also noted on X-ray.

All the animals in group $\mathrm{C}$ showed some affection of the skeletal structures, with marked persistent lameness. Two of the pups showed extreme unwillingness to stand or walk although no fractures were present. Later, pathological fractures occurred in the bones of four of the pups, and all were destroyed. Slight bending of the forelegs occurred and some of the pups exhibited marked distortion at the carpus, allowing plantigrade stance. On $\mathrm{X}$-ray these pups all showed severe rarefaction of the skeleton with very thin pencil-line cortices. In many of them there were denser areas at the metaphyses, but in only two of the pups were signs of rickets seen, and one of these showed only very slight rachitic changes. Both these pups were on the lower vitamin $D$ intake. 
Four of the pups in group $\mathrm{C}$ showed pathological fractures, pups on low as well as those on high vitamin $\mathrm{D}$ intake being affected. The bones which were fractured were the femurs, tibias and pelvis, several fractures occurring in some of the pups (Pl. I $b$ ).

Biochemical findings. The results of serial determinations of plasma $\mathrm{Ca}, \mathrm{P}$ and alkaline phosphatase are shown in Figs. I, 2 and 3 , respectively. The control animals showed only slight variation in all the constituents measured. In group B, however, the plasma Ca level showed a marked fall from the 8th week onward, values less than

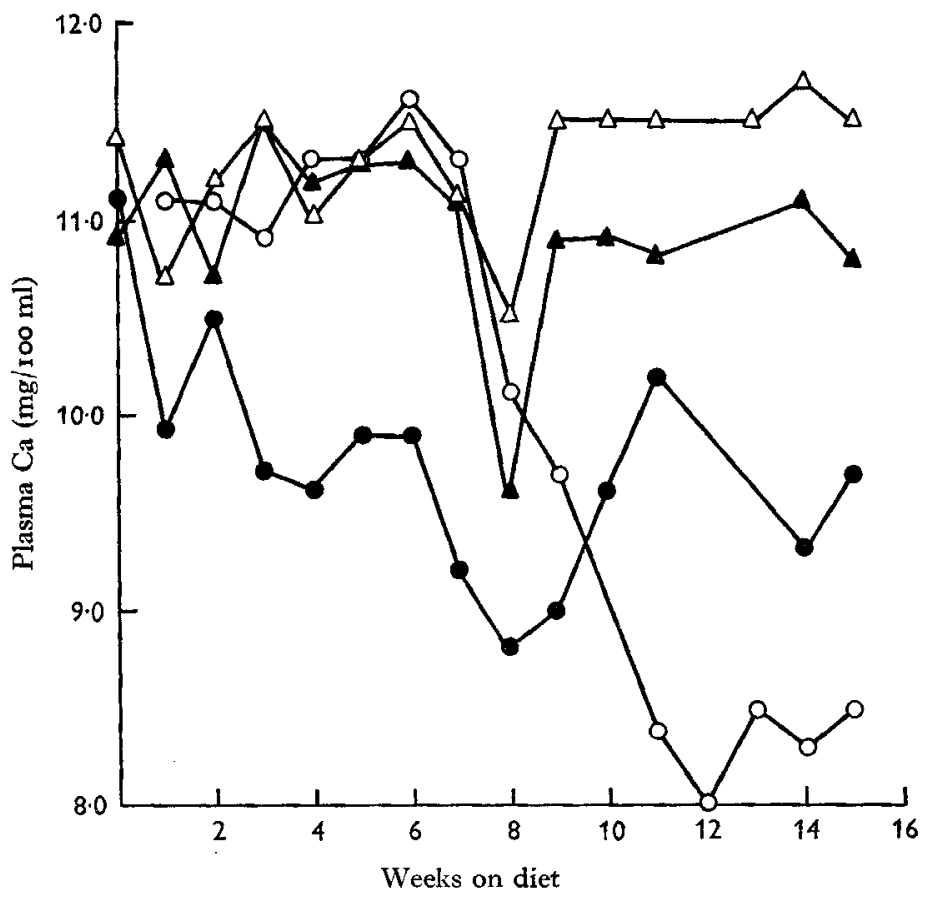

Fig. I. Mean weekly plasma calcium levels for groups of pups given various diets. $\Delta-\Delta$, (control) high-Ca diet; $0_{-O}$, low-Ca diet unsupplemented; $1-\Delta$, low-Ca diet with high vitamin D supplement; $\bullet-\bullet$, low-Ca diet with low vitamin D supplement.

$8 \mathrm{mg} / \mathrm{roo} \mathrm{ml}$ being observed. Plasma phosphate at the same time showed no significant change. In group $C$ the animals receiving the lower dose of vitamin $D$ showed a fall in plasma $\mathrm{Ca}$, values between $9^{-10} \mathrm{mg} / \mathrm{I} 00 \mathrm{ml}$ being maintained throughout most of the experimental period. The rapid fall (after $\mathrm{I}$ week on the diet) in plasma Ca observed in this group may have reflected the previous dietary history of these animals, but no relevant information is available. On the high intake of vitamin $D$ the values for $\mathrm{Ca}$ were rather variable but most of them were around I $\mathrm{mg} / \mathrm{IOO} \mathrm{ml}$.

In both groups $\mathrm{B}$ and $\mathrm{C}$ the mean values for alkaline phosphatase were higher than in the control animals, but there was considerable variation in the levels for the different animals.

Table I shows the mean plasma values for $\mathrm{Ca}, \mathrm{P}$ and alkaline phosphatase for each group. In order to obtain a sharper comparison of the dietary effects, the mean values 
up to the 7 th week have been calculated separately from the mean values from the 8th week to the end of the experimental period. All the mean values remained within normal limits in group $\mathrm{A}$. In group $\mathrm{B}$ the mean $\mathrm{Ca}$ level in the 2nd period was significantly lower than in the control group $(P<0.001)$. In group $\mathrm{C}$ the difference in level of the vitamin D supplement was reflected only in the plasma Ca values. With the low supplement the $\mathrm{Ca}$ level was significantly lower than in the control group $(P<0.001)$, whereas with the high vitamin $\mathrm{D}$ supplement the $\mathrm{Ca}$ levels did not differ significantly from the control value.

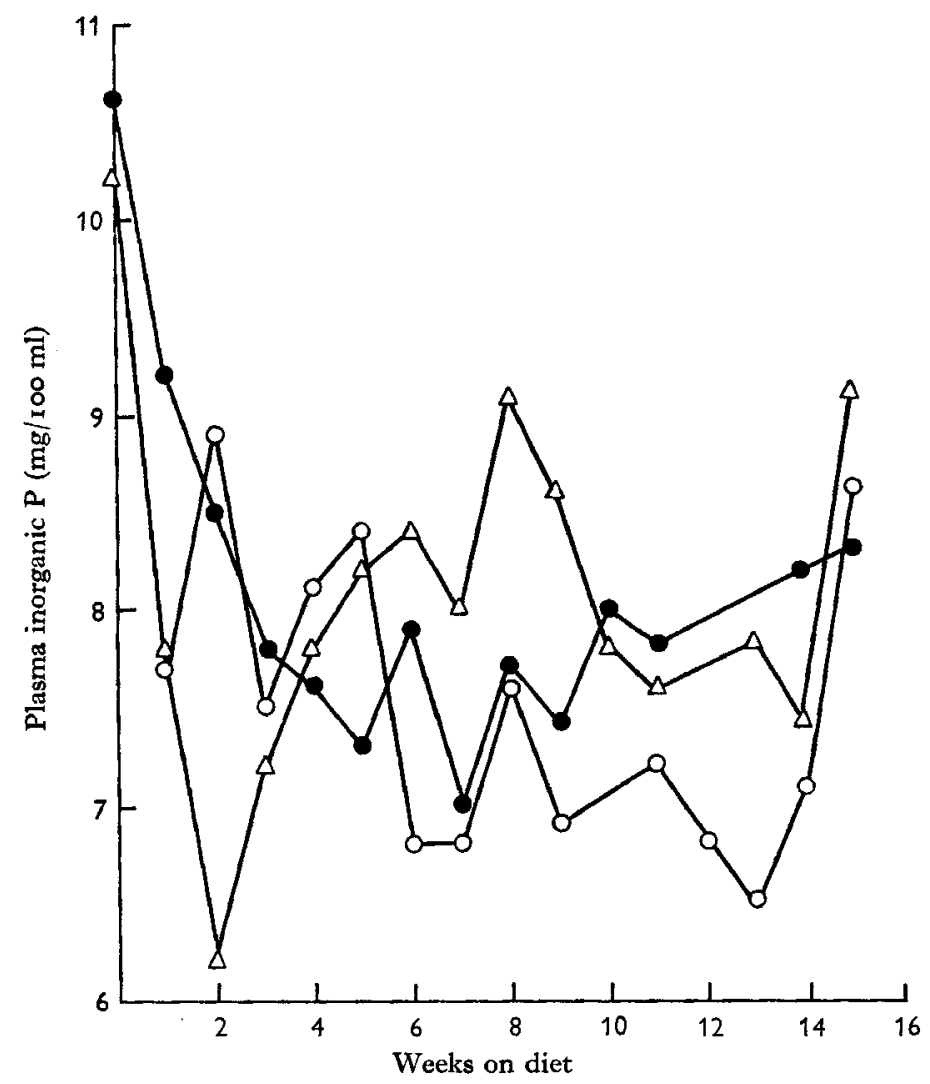

Fig. 2. Mean weekly plasma inorganic phosphorus levels for groups of pups given various diets. $\Delta-\Delta$, (control) high-Ca diet; $0-0$, low-Ca diet unsupplemented; $-\bullet$, low-Ca diet with vitamin D supplements.

In groups $\mathrm{B}$ and $\mathrm{C}$ there was a significant increase in the content of plasma alkaline phosphatase $(P<0.001)$. No significant change in plasma phosphate concentration was seen in any of the groups.

Histological findings. Histological evidence of rickets with thickening and distortion of the epiphysial plate was found in the sections of bone from the animals receiving only the deficient diet B. The control pups showed no such changes. In two of the pups receiving the lower dose of vitamin $\mathrm{D}$ rachitic changes could be seen. In all the other pups in group $\mathrm{C}$ normal maturation of the epiphysial cartilage was occurring. 
The bones of the control pups were dense with thick well-formed cortices (Pl, 2a). In groups $\mathrm{B}$ and $\mathrm{C}$, on the other hand, some degree of rarefaction could be seen in the bones $(\mathrm{Pl} .2 b)$, which was most marked in the group receiving the supplements of vitamin $\mathrm{D}$. In these animals the cortical bone was very thin and porous, both in the long bones and in the skull. In the metaphysial area in some of the bones (Pl. 2c) areas of disruption, with microscopical fractures, were present. Often in association with these areas, masses of fibrous tissue and cartilage were seen. Fibrous tissue was

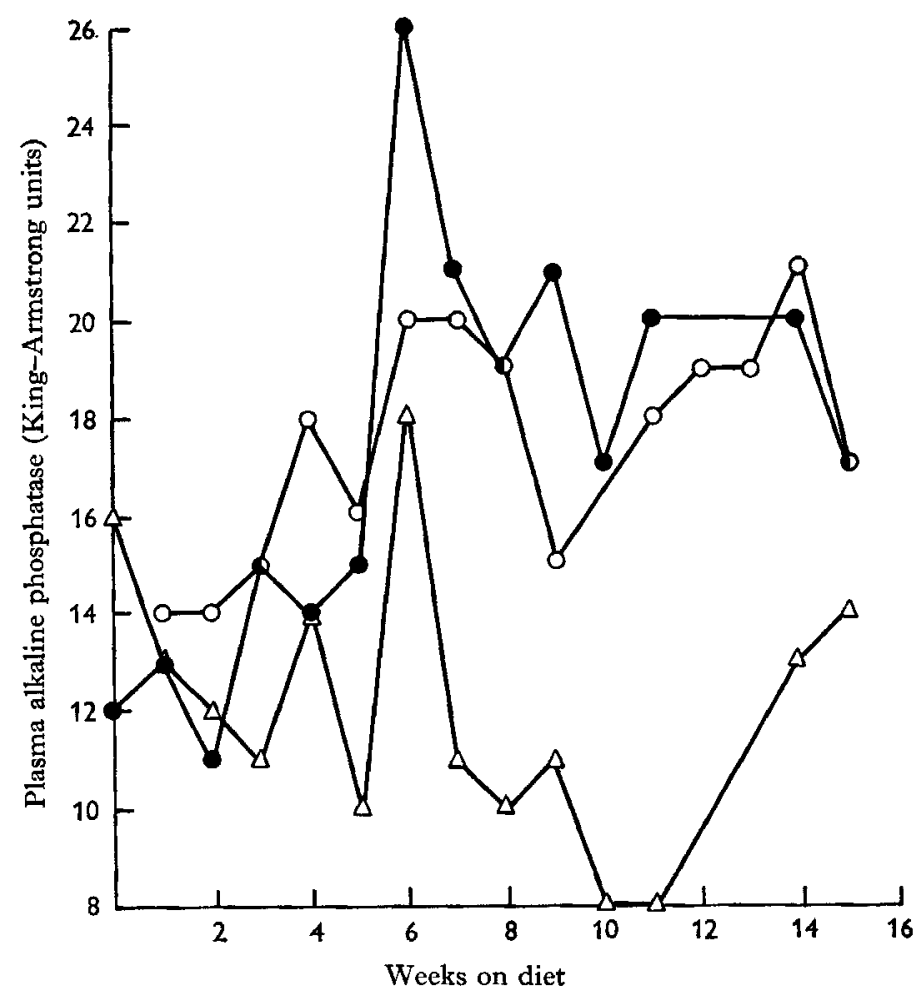

Fig. 3. Mean weekly plasma alkaline phosphatase levels for groups of pups given various diets. $\Delta-\Delta$, (control) high-Ca diet; $\circ-0$, low-Ca diet unsupplemented; $-\bullet$, low-Ca diet with vitamin $\mathrm{D}$ supplements.

also present in large amounts down the shaft in the subperiosteal region (PI. $2 d$ ) and numerous osteoclasts were present in all the bone sections.

Copper, haemoglobin and urea concentrations and erythrocyte count of the blood. Determinations of $\mathrm{Cu}$ were made on blood and liver samples from three of the pups receiving no supplement of minerals or vitamin $\mathrm{D}$. The blood $\mathrm{Cu}$ levels after I I weeks on the diet were $0.04,0.07$ and $0.08 \mathrm{mg} / \mathrm{roo} \mathrm{ml}$ whole blood. Liver samples taken post mortem from the same animals were found to contain 4, 19 and $9 \mathrm{ppm}$ (wet weight), respectively, i.e. within the lower limit of normal (Hartley, Kater \& Mackay, 1963).

Haemoglobin determinations carried out on eight pups receiving the low-Ca diet showed normal values for each animal and the erythrocyte counts were also within normal limits. 


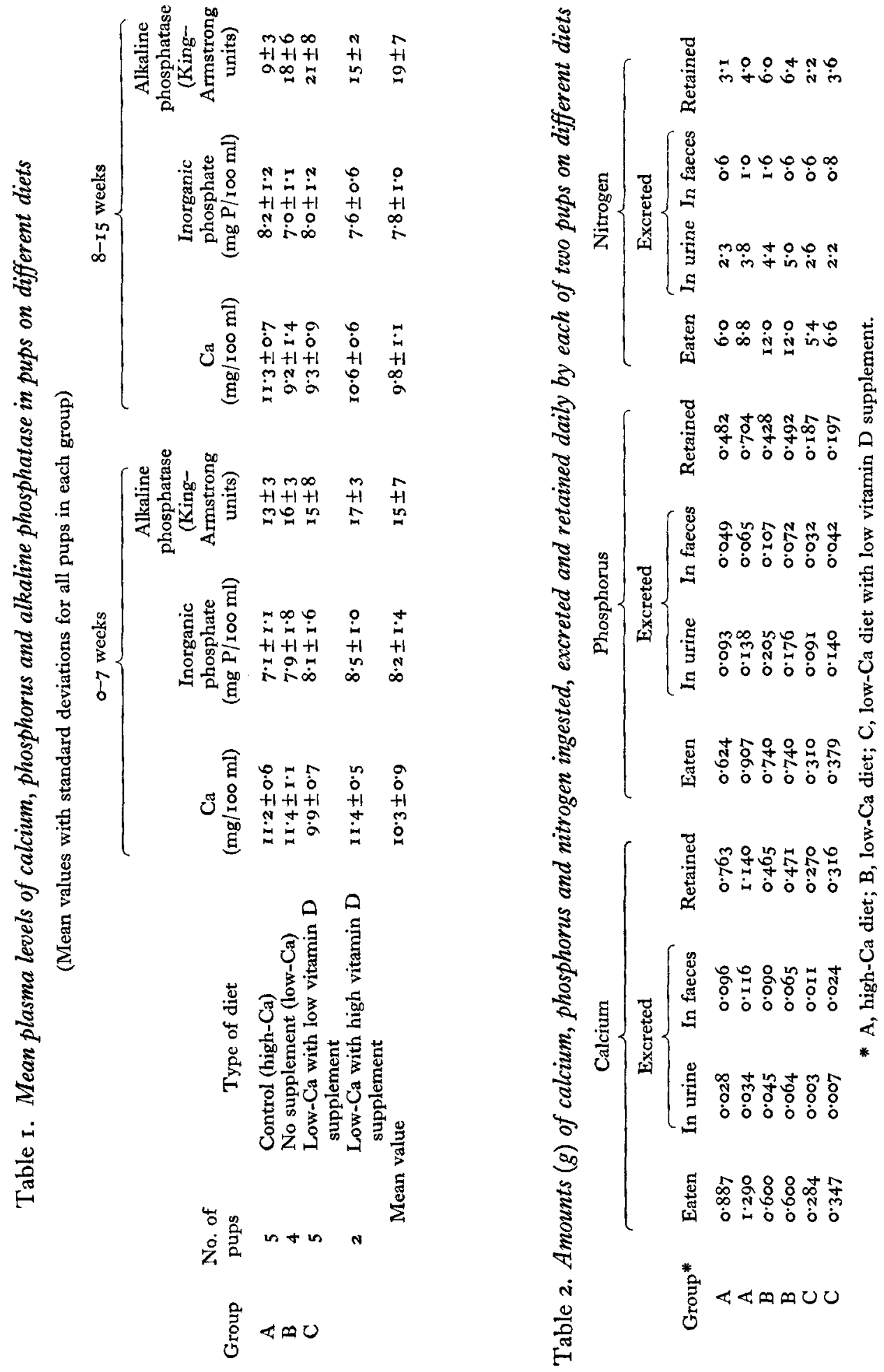




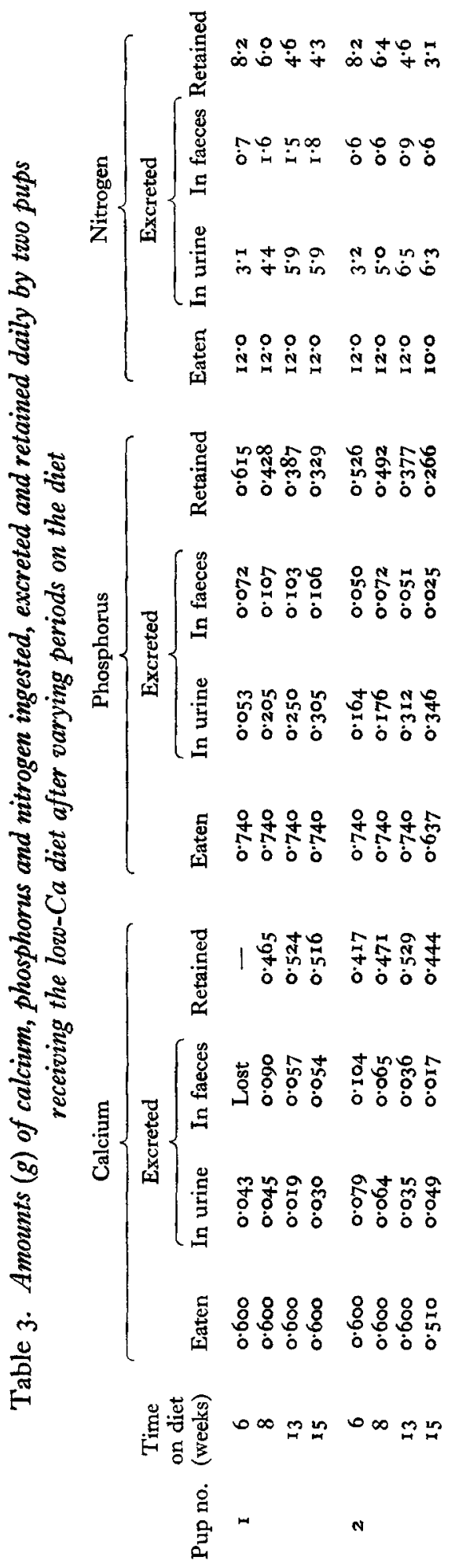


Blood urea determinations carried out at irregular intervals showed no evidence of renal dysfunction.

Balance studies. The results of the studies made on two pups from each group after they had been maintained for 8 weeks on the diet are shown in Table 2. Administration of vitamin $\mathrm{D}$ (group C) caused a reduction in faecal and urinary $\mathrm{Ca}$, but both pairs of pups receiving the low-Ca diet (groups $\mathrm{B}$ and $\mathrm{C}$ ) retained much less $\mathrm{Ca}$ than the controls. The animals receiving the supplement of vitamin $D$ generally ate less food than the other pups, but no effect on the percentage excretion of $\mathrm{P}$ or $\mathrm{N}$ was detectable.

The composite results of serial balances with the pups receiving the Ca-deficient diet alone are shown in Table 3. There was a progressive decrease in the excretion of $\mathrm{Ca}$, with at the same time a rise in the excretion of $\mathrm{N}$, mainly in the urine.

\section{DISCUSSION}

The term rickets is often used loosely to describe skeletal abnormalities in dogs in which the aetiological factors and the radiographic and histological appearance have not been determined. This has led to confusion in the diagnosis and description of such bone disorders.

Both rickets and osteoporosis have been produced by dietary means in the experiments described in this paper. With the same diet but with vitamin $\mathrm{D}$ given, the bone changes were altered in that rickets was reduced or absent but the osteoporosis was more severe. The lower dose of vitamin $D$ did not completely prevent rachitic changes.

The therapeutic and prophylactic effects of vitamin D on rickets have long been recognized (Mellanby, I92I; McCollum, Simmonds, Shipley \& Park, 192I). It has previously been recorded, however, that vitamin $\mathrm{D}$ may be unable to prevent completely the rachitic effects of a diet that is seriously inadequate in mineral content (Korenchevsky, 1922; Marek \& Wellman, I931; Morgan, 1940).

Since none of the control animals, which received mineral supplements but no added vitamin $\mathrm{D}$, developed rickets in these experiments it is probable that pups only require additional vitamin $\mathrm{D}$ when there is mineral deficiency or imbalance in the diet. This is so with rats (Pappenheimer, McCann \& Zucker, 1922), and the same findings in dogs have been reported previously (Marek \& Wellman, I93 ; Freeman \& McLean, 194I; Sjöberg, 1942; Hutyra, Marek \& Manninger, 1949).

Poor growth has been described in animals receiving diets low in Ca (Sherman \& Pappenheimer, 1921; Impey \& Moore, 1962). Administration of vitamin D in these circumstances usually ameliorates the condition (McCollum $e$ t al. 1921) but poorer growth than normal has also been produced (Jaffe, Bodansky \& Chandler, 1932; Fraser, Godden \& Auchinachie, 1934). The reduction in weight gain (see p. 34.1) in the pups with the high intake of vitamin $D$ probably indicates some degree of intoxication.

In the pups which were given vitamin $\mathrm{D}$ in conjunction with the $\mathrm{Ca}$-deficient diets skeletal abnormalities were produced, in some very severe. Clinically the animals showed lameness and sometimes extreme reluctance to stand and walk. In several the lameness was found to be associated with one or more pathological fractures. When 
reluctance to walk was not associated with fractures it may have been due to skeletal and muscular pain such as has been noted by Rose ( 1960$)$ in bone dystrophies.

That vitamin $D$ is able to cause bone resorption has been demonstrated by numerous workers (Watchorn, 1930; Harris \& Innes, 1931 ; Harris, 1932; Crawford, Gribetz, Diner, Hurst \& Castleman, 1957). All the evidence in our studies supports the view that the administration of vitamin $\mathrm{D}$ increased bone destruction, maintaining the levels of circulating mineral at the expense of the skeletal tissues. This may be deduced from the increase in osteoporosis which occurred in the vitamin D-treated animals and which has been recognized on radiological, biochemical and histological examination. In all the animals given the vitamin supplement the plasma $\mathrm{Ca}$ values were maintained at a higher level than was seen in the unsupplemented group.

At the same time, however, there was no evidence that the higher blood levels were due to greater absorption of $\mathrm{Ca}$ even though a greater proportion of the dietary $\mathrm{Ca}$ was absorbed. In fact, mineral balances showed that the pups given vitamin $\mathrm{D}$ were retaining less $\mathrm{Ca}$ than the groups not given the vitamin and very much less than the controls.

It would thus appear that the effect of vitamin $\mathrm{D}$ in circumstances of Ca deficiency is to prevent, or reduce, a fall in the level of plasma $\mathrm{Ca}$ by increasing the rate of bone resorption. If the plasma levels of $\mathrm{Ca}$ and $\mathrm{P}$ are raised sufficiently, the rachitic changes which would otherwise appear as a result of $\mathrm{Ca}$ deficiency are prevented. Thus vitamin $\mathrm{D}$ causes a redistribution of the mineral within the bone. This redistribution has been commented upon previously by Harris \& Innes (I93I) and Mellanby (I934). Other causes of osteoporosis such as $\mathrm{Cu}$ deficiency, avitaminosis $\mathrm{C}$ and renal dysfunction, have been ruled out as far as possible.

A striking feature on histological examination was the presence of subperiosteal fibrous tissue. The largest deposits of fibrous tissue occurred in the region of the bone shoulders where the diaphysial cortex deviates laterally to the wider epiphysis. This is the region where the fastest rate of bone remodelling is taking place (LeBlond, Wilkinson, Bélanger \& Robichon, 1950). Some authorities consider that the fibrous tissue found in bones may be a type of scar tissue (McLean \& Bloom, I937). It has also been suggested, however, that these cells are not fibrocytes but are the result of a dedifferentiation of osteoblasts (Wilton, 1946). The appearance of this tissue, nevertheless, implies a considerable amount of bone destruction (Follis, 1953).

The occurrence of unresolved areas of cartilage in the diaphyses of the bones has been described by several authors. Holmes \& Price (1957) found these changes in the bones of a pup in which they diagnosed osteogenesis imperfecta. It has also been shown that excess vitamin D may cause a condition in which areas of unresolved cartilage are found in the bones (Ham \& Lewis, I934; Follis, 1953). It is possible that in our experiments the cartilage has been laid down in response to stresses within the bone. During the stages of healing of a fracture, cartilage is laid down among the fibrous tissue which is first formed in response to the fracture (Watson-Jones, I946). Microscopical fractures in the metaphysial region were seen in some of the histological preparations in our study, and it is thought possible that some of the fibrous and cartilaginous tissue may have been produced in response to such traumatic episodes. 
Similar areas of fibrous tissue growth were found by Becks \& Weber (1931) and Morgan (1934) as a result of $\mathrm{Ca}$ deficiency whether or not a supplement of cod-liver oil was given. In cases where there is excessive bone resorption there is also an increase in the number of osteoclasts (Hancox, 1956). In the bones of the animals in our study which were receiving vitamin $D$ there was, in addition to an increase in fibrous tissue, a marked increase in the number of osteoclasts.

The animals in these experiments that were given the deficient diet at the earliest age ( 6 weeks) showed the most rapid and extensive changes. It has been reported that during the suckling period young animals show a decrease in the $\mathrm{Ca}$ content of the bones (Sjöberg, 1942; Slater \&Widdowson, 1962). The sooner after weaning, therefore, the animal is subjected to conditions of Ca deficiency, the more likely are skeletal changes to occur. Impey \& Moore (1962) have demonstrated that rats show progressively more severe bone damage as the period after weaning before they are given $\mathrm{Ca}$-deficient diets is reduced.

Increased resistance to bone lesions with age may be due to increased efficiency of $\mathrm{Ca}$ retention. The two pups receiving the $\mathrm{Ca}$-deficient diet on which serial balance studies were carried out showed a decrease in excretion of $\mathrm{Ca}$ over the experimental period. That dogs have the capacity to accommodate to a Ca-deficient diet, even when the deficiency is extreme, has already been demonstrated by Gershoff, Legg \& Hegsted (1958). Whether the decreased excretion of the element demonstrated in our experiments is due to this capacity to accommodate or was a function of the age of the animal is not known. It was, however, probably a combination of the two factors. These factors may account for the spontaneous recovery which is shown by pups suffering from pathological fractures.

These balance studies also showed a progressive fall in the retention of $\mathrm{P}$ and $\mathrm{N}$ by these pups, indicating the normal reduction with age in the rate of growth. Such a reduction in growth would reduce the requirements for all food constituents, so that this factor also would protect an older animal against an inadequate diet.

The animals used by us were all mongrel pups of medium size, yet sufficiently severe bone changes were produced to cause pathological fractures. Riser (I96I) has described the development of pathological fractures in pups fed on a diet of beef heart and water. It has previously been noted (Hutyra et al. 1949) that the requirements for $\mathrm{Ca}$ and $\mathrm{P}$ vary with the rate of growth, so that the larger, more rapidly growing dogs will be more susceptible to skeletal damage caused by dietary deficiencies of minerals. Since the type of diet used in our investigation was very similar to that used by many dog owners and breeders, the results of these experiments may have some bearing on clinically occurring bone diseases.

\section{SUMMARY}

I. Young growing dogs were maintained on a diet deficient in calcium; one group received supplements of calcium and phosphorus; one group received no supplement whatsoever; one group received supplements of vitamin $\mathrm{D}$. The effects of the diets on blood $\mathrm{Ca}$ and $\mathrm{P}$ levels and bone development were studied by means of biochemical analysis, metabolic balances, and radiological and histological examination. 
2. The provision of $\mathrm{Ca}$ and $\mathrm{P}$ without vitamin $\mathrm{D}$ prevented bone abnormalities.

3. A diet deficient in $\mathrm{Ca}$ and $\mathrm{P}$ and vitamin $\mathrm{D}$ resulted in rickets complicated by osteoporosis.

4. Supplementation with vitamin $D$ in circumstances of $\mathrm{Ca}$ and $\mathrm{P}$ deficiency reduced or prevented the occurrence of rickets. Erosion and resorption of bone was more intense, resulting in osteoporosis with the occurrence of pathological fractures.

5. Over a series of 3-day balance periods decreased excretion of $\mathrm{Ca}$ and increased excretion of $\mathrm{P}$ and nitrogen were noted in animals receiving the deficient diet without supplementation.

6. Increase in the amount of fibrous tissue associated with the bones was found in the animals receiving the low $\mathrm{Ca}$ intake with vitamin $\mathrm{D}$ supplements.

7. Possible reasons for these findings are discussed.

\section{REFERENCES}

Becks, H. \& Weber, M. (1931). F. Amer. dent. Ass. 18, 197.

Campbell, J. R. (1960). Vet. Rec. 72, I 153.

Carlsson, A. \& Lindquist, B. (1955). Acta physiol. scand. 35, 53.

Crawford, J. D., Gribetz, D., Diner, W. C., Hurst, P. \& Castleman, B. (1957). Endocrinology, 6r, 59.

Eden, A. \& Green, H. H. (1940). Biochem. Y. 34, I202.

Fiske, C. H. \& Subbarow, Y. (1925). F. biol. Chem. 66, 375.

Follis, R. H. (1953). Trans. Conf. Metab. Interrelat. 5, 196.

Fraser, A. H. H., Godden, W. \& Auchinachie, D. W. (I934). Biochem. F. 28, 157.

Freeman, S. \& McLean, F. C. (194I). Arch. Path. (Lab. Med.) 32, 387.

Gershoff, S. N., Legg, M. A. \& Hegsted, D. M. (r958). J. Nutr. 64, $3 \circ 3$.

Greaves, J. P., Scott, P. P. \& Scott, M. G. (1958). Proc. Nutr. Soc. r7, xlvii.

Ham, A. W, \& Lewis, M. D. (1934). Brit. F. exp. Path. 15, 228.

Hancox, N. (1956). In The Biochemistry and Physiology of Bone, p. 2r3. [G. H. Bourne, editor.] New York: Academic Press Inc.

Harris, L. J. (1932). Lancet, i, 1031.

Harris, L. J. \& Innes, J. R. M. (1931). Biochem. 7. 25, 367.

Hartley, W. J., Kater, J. C. \& Mackay, A. (I963). N.Z. vet. F. II, I.

Herndon, C. N. (1956). Clin. Orthopaed. 12, 132.

Holmes, J. R. \& Price, C. H. G. (1957). Vet. Rec. 69, 1047.

Hutyra, F., Marek, J. \& Manninger, R. (1949). Special Pathology and Therapeutics of the Diseases of Domestic Animals. Vol. 3. London: Baillière, Tindall and Cox.

Impey, S. G. \& Moore, T. (1962). Proc. Nutr. Soc. 21, xxxvii.

Jaffe, H. L., Bodansky, A. \& Chandler, J. P. (1932). F. exp. Med. 56, 823.

Kabat, E. A. \& Mayer, M. M. (1961). Experimental Immunochemistry, and ed. Springfield, Ill.: C. C. Thomas.

King, E. J. \& Armstrong, A. R. (1934). Canad. med. Ass, F. 31, 376.

King, E. J., Haslewood, G. A. D. \& Delory, G. E. (1937). Lancet, i, 886.

Korenchevsky, V. (1922). Spec. Rep. Ser. med. Res. Coun., Lond., no. 71.

Kramer, B. \& Tisdall, F. F. (r921). 7. biol. Chem. 47, 475.

LeBlond, C. P., Wilkinson, G. W., Bélanger, L. F. \& Robichon, J. (1950). Amer. F. Anat. 86, 289.

McCance, R. A. \& Widdowson, E. M. (1960). Spec. Rep. Ser. med. Res. Coun., Lond., no. 297.

McCollum, E. V., Simmonds, N., Shipley, P. G. \& Park, E. A. (192 I). Proc. Soc. exp. Biol., N, Y., r8, 267.

McLean, F. C. \& Bloom, W. (1937). Science, 85, 24.

Marek, J. \& Wellman, O. (193I). Die Rachitis in ihren Atiologischen, Biochemischen, Pathogenetischen, Pathologisch-anatomischen und Klinischen Beziehungen. Pathologischer Teil (J. Marek). Jena: Gustav Fischer.

Mellanby, E. (I921). Spec. Rep. Ser. med. Res. Coun., Lond., no. 6r.

Mellanby, E. (1934). Nutrition and Disease. London: Oliver and Boyd.

Morgan, A. F. (1934). Univ. Calif. Publ. Physiol. 8, 6r.

Morgan, A. F. (1940). N. Amer. Vet. 21, 476.

Pappenheimer, A. M., McCann, G. F., \& Zucker, T. F. (I922). \%. exp. Med. 35, 447.

Riser, W. H. (ı66r). F. Amer. vet. med. Ass. r39, 117. 


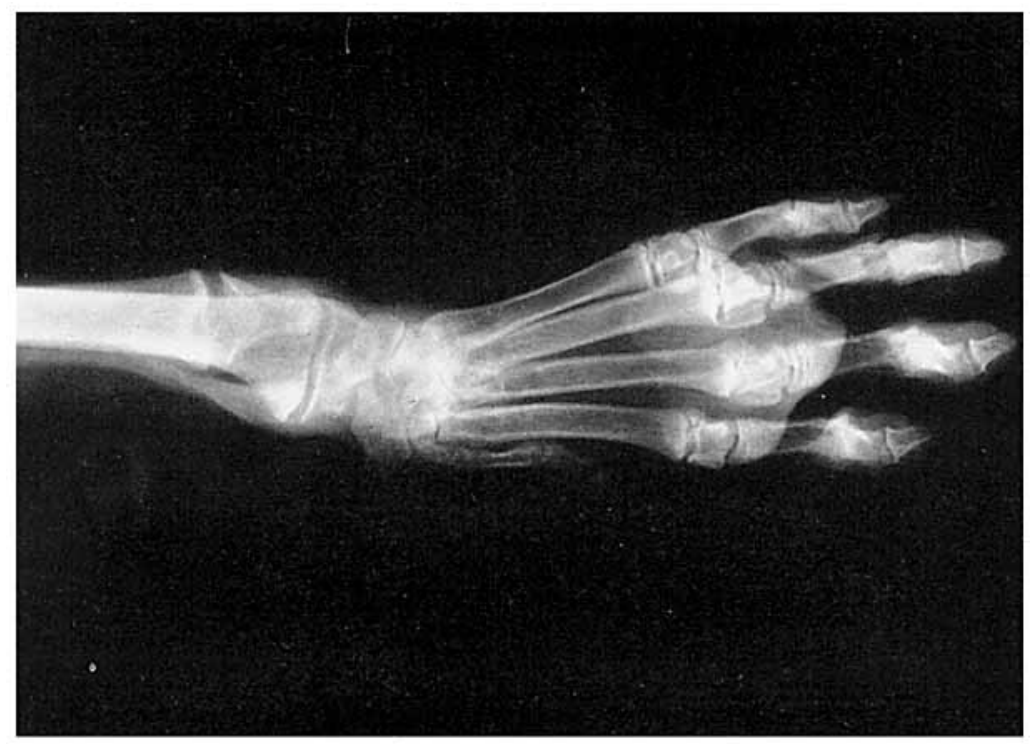

(a)

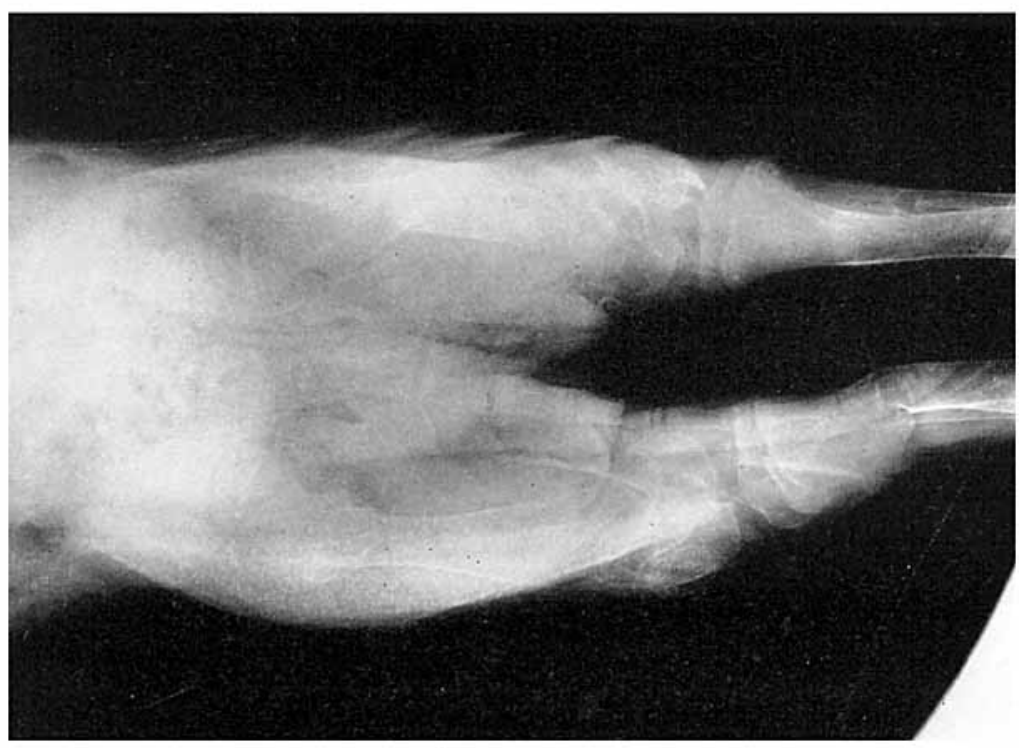

(b) 


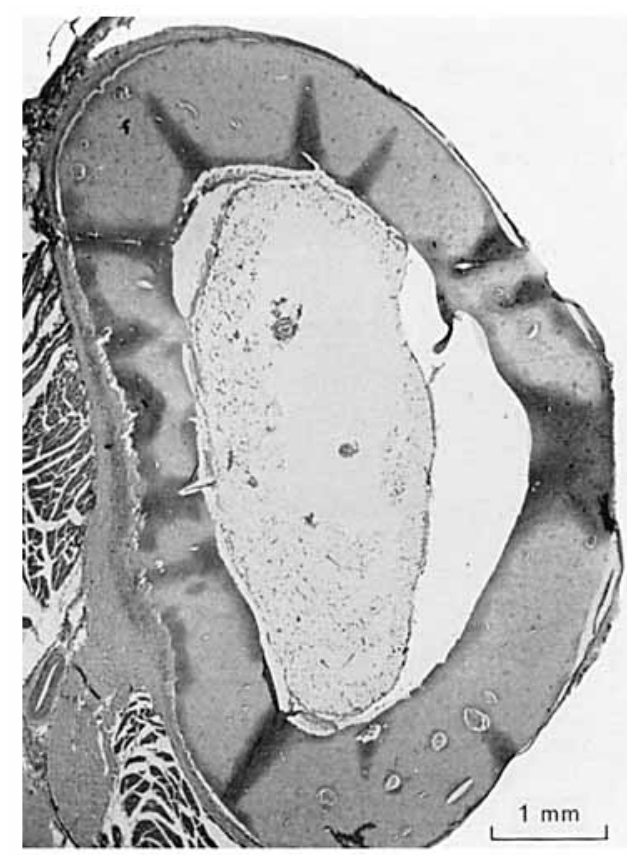

(a)

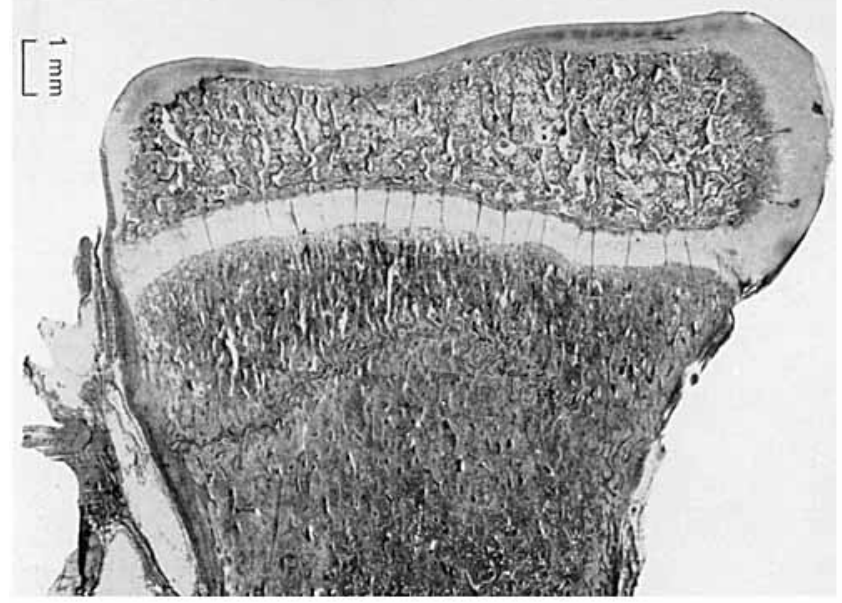

(c)

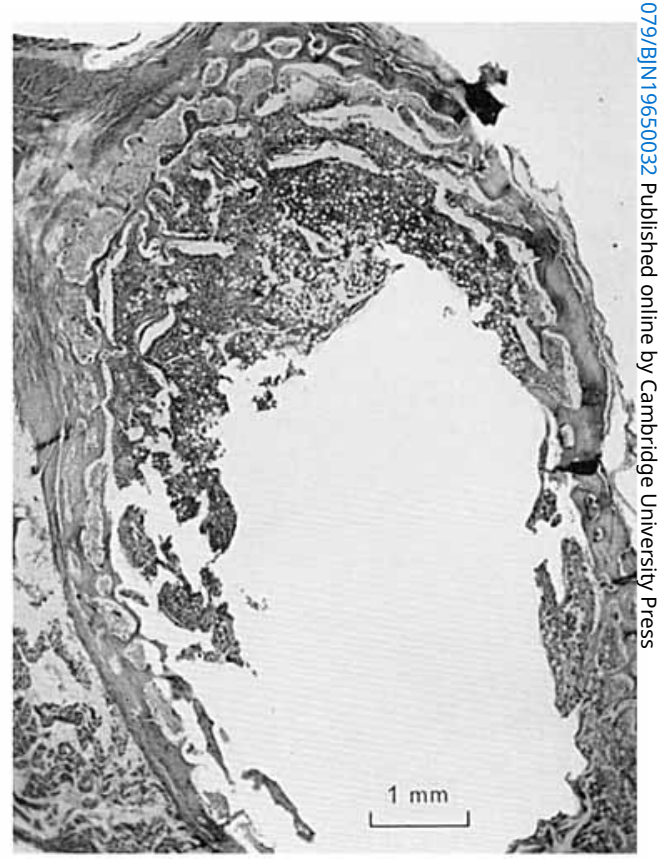

(b)

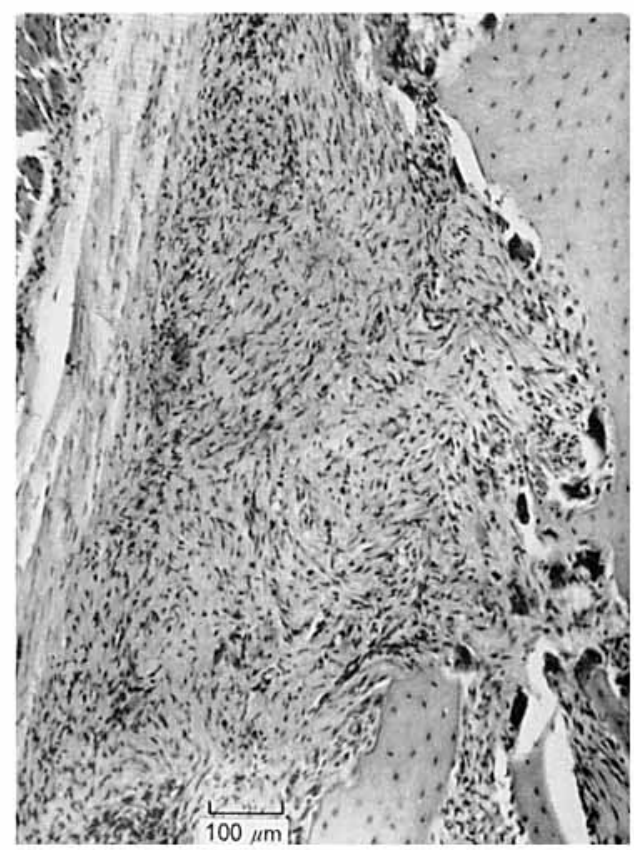

(d)

J. R. CAMPBEI.I, AND T. A. DOUGLAS 
Rose, G. A. (1960). Recent Advances in Clinical Pathology, p. 124. Series 3. London: J. and A. Churchill.

Schnelle, G. B. (1940). N. Amer. Vet. 21, 738.

Sherman, H. C. \& Pappenheimer, A. M. (I921). Proc. Soc. exp. Biol., N.Y., 18, I93.

Sjöberg, K. (1942). Kungl. Lantbruksakad. Tidskr. 81, 1 37.

Slater, J. E. \& Widdowson, E. M. (1962). Brit. F. Nutr. 16, 39.

Varley, H. (1958). Practical Clinical Biochemistry. London: Heinemann.

Watchorn, E. (1930). Biochem. F. 24, 63I.

Watson-Jones, R. (1946). Fractures and Yoint Injuries. Vol. I. Edinburgh: E. and S. Livingstone Ltd.

Williams, M. B. \& Moser, J. H. (1953). Analyt. Chem. 25, 1414.

Wilton, A. (1946). Acta path. microbiol. scand. 23, I.

\section{EXPLANATION OF PLATES}

Plate I

(a) Radiograph of a forelimb of a pup given a low-calcium diet, showing rachitic enlargement of the epiphysial cartilage.

(b) Radiograph of the hind limbs and pelvis of a pup given a low-calcium diet with low vitamin D supplement, showing poor skeletal mineralization and fractures of both femurs and one tibia.

\section{Plate 2}

(a) Photomicrograph of a transverse section of the radius of a pup given a high-calcium diet, showing thick, dense, well-formed cortical bone. Haematoxylin and eosin.

(b) Photomicrograph of a transverse section of the radius of a pup given a low-calcium diet with low vitamin D supplement, showing extremely thin atrophic cortex. Haematoxylin and eosin.

(c) Photomicrograph of the metaphysial area of the radius of a pup given a low-calcium diet with low vitamin $D$ supplement, showing a crush fracture across the metaphysis as a result of folding together of the small, weak trabeculae in the region. Haematoxylin and eosin.

(d) Photomicrograph of a longitudinal section of the shaft of the radius of a pup given a low-calcium diet with low vitamin D supplement. Osteoclastic erosion of the bone is well marked, and a large amount of fibrous tissue is present in the region. Haematoxylin and eosin. 